\title{
FEMALE FRIENDSHIPS IN ANA PLÁCIDO AND GUIOMAR TORRESÃO: \\ COMMUNITIES AND LEGACIES OF WOMEN READERS AND WRITERS
}

ESTELA VIEIRA

Indiana University

evieira@indiana.edu

ABSTRACT: This essay will focus on two nineteenth-century Portuguese women writers, Ana Plácido (1831-1895) and Guiomar Torresão (1844-1898). Women's writing in Portugal before 1900 remains vastly understudied. This essay aims to remedy this historical neglect by analyzing and reading two decisive works by these writers, Plácido's Herança de lágrimas (1897) and Torresão's Uma alma de mulher (1869). While attempting to integrate their writing into canonical and feminist traditions and situate their work in the shifting frameworks of romanticism, I examine how these novels build through complex plot twists and narrative structure, communities of women readers, writers, and intellectuals. These figures, whether fictional or real, serve as companions for the female characters and the women writers. In both of these neglected works we see how the authors privilege female solidarity, building a consciousness of a legacy of women writers, readers, and intellectuals that albeit mostly fictional resound to contradict the idea that women played a minor role in the Lusophone nineteenth-century literary milieu. While following certain conventions of romanticism these works suggest through their narrative devices and structure alternatives for their female protagonists, and thus challenge definitions of the romantic genre and of the romance plot while at the same time questioning the limitations on women's social and intellectual roles.

KEYWORDS: Portuguese women writers, Ana Plácido, Guiomar Torresão, nineteenth-century novel, romanticism, romance plot. 


\section{AMISTADES FEMENINAS EN ANA PLÁCIDO Y GUIOMAR TORRESÃO comunidades y legados de lectoras y escritoras}

RESUMEN: Este artículo estudia dos escritoras portuguesas del siglo XIX, Ana Plácido (1831-1895) y Guiomar Torresão (1844-1898). La escritura de mujeres portuguesas anterior a 1900 sigue contando con muy pocos estudios. Este artículo se propone paliar esa carencia historiográfíca por medio del análisis y la lectura de dos obras clave de escritoras de ese período: Herança de lágrimas (1897) de Plácido y Uma alma de mulher (1869) de Torresão. Aunque se procura integrar su producción en las tradiciones canónica y feminista y situar su obra en el contexto fluctuante del romanticismo, se estudia cómo en esas novelas se crean, a través de giros complejos de la trama y de las estructuras narrativas, comunidades de lectoras, escritoras y mujeres intelectuales. Estas figuras, ya sean ficticias o reales, acompañan a los personajes femeninos y a las escritoras. En estas dos obras ignoradas se observa cómo las autoras subrayan la solidaridad femenina y crean conciencia de un legado de escritoras, lectoras e intelectuales en femenino que, siquiera en la ficción, contribuyen a combatir la idea de que las mujeres desempeñaron un papel menor en el ambiente literario luso del siglo XIX. Aunque siguen algunas convenciones románticas, estas obras, por medio de sus técnicas narrativas y de sus variantes estructurales, proponen alternativas para sus protagonistas femeninas, con lo que desafían las definiciones del género romántico y la trama novelesca, a la par que cuestionan las limitaciones en los roles sociales e intelectuales de las mujeres.

PALARAS CLAVE: Escritoras portuguesas; Ana Plácido, Guiomar Torresão, novela del siglo XIX, romanticismo, tramas amorosas.

$\mathrm{M}$ odern readers and critics face numerous challenges when reading the mostly neglected, often inaccessible, sometimes harshly criticized, and still very little critically read and interpreted work of Portuguese nineteenth-century women writers. Figures that have become more invisible today than they were during their active creative lives. Literary criticism is scant on their work, and despite increased recent interest in the field, a sense of regret tends to prevail the discussion. Critics lament the fact that Portugal never produced a female writer comparable to a George Sand or a Jane Austen, and generally provide rather quick and pessimistic readings of this textual production. This presumed failure of nineteenth-century Portuguese women writers epitomizes the critical assessment of female literary contributions to nineteenth-century Portuguese letters and remained until very recently the prevailing conversation. Teresa Leitão de Barros's 1924 Escritoras de Portugal, arguably the first critical attempt to conceptualize a female literary legacy in Portugal, is often preoccupied with rationalizing the insufficiency and limitations of the writers. Isabel Allegro de Magalhães (1987), a key scholar of Portuguese feminist writing, is disappointed nineteenth-century Portuguese female authors do not compare to their European counterparts. While Cláudia de Pazos Alonso (1996) contextualizes the asymmetry historicizing the development of women writers along the century, and in her new book, Francisca Wood and Nineteenth-Century Periodical Culture: Pressing for Change (2020), revisits the generally overlooked pioneering qualities of mid-nineteenth-century female authorship. In her essay, Kathryn Bishop-Sanchez begins the debunking of the "mito da 'esterilidade' literária feminina" by considering the work of nineteenth-century writer Antónia Gertrudes Pusich (2017: 171).

In this essay, I too attempt to move beyond this sense of disappointment by delving into an analysis of two examples of these women's writing: Ana Plácido's (1831-1895) Herança de lágrimas (1871) and Guiomar Torresão's (1844-1898) Uma alma de mulher (1869). Both are striking novels in which the authors privilege female solidarity and build within their texts a consciousness of a legacy of women writers, readers, and intellectuals that - albeit fictional-resound to contradict the idea that women played a minor part in the Lusophone nineteenth-century literary milieu. While following certain romantic conventions and creating specific romance plots these works also rearrange these suggesting through plot devices different alternatives for their female protagonists, and thus challenging definitions of the romantic genre and of the romance plot while at the same time questioning the limitations on women's social and intellectual roles. In both stories, we have orphaned young women 
who either end up (or almost) in unhappy marriages or with unfortunate fates, but who along the way find intellectual strength by identifying with other women. These female friendships are forged sometimes directly and other times discursively within the complex layout of the narrative. The stories build within their plot and formal features female communities and legacies, which are narratively constructed generating a sense of support for the fictional female characters and for the real women writers. While remaining dubious of the critical reception these writers have received, I will try to elucidate the complex context within which they published and consider and interpret their writing on their own terms, pointing to some theoretical possibilities to rethink how this work disrupts and contributes to our established literary and cultural histories.

In the first of the four sections of this essay, “The Lettered Workwoman," I discuss Guiomar Torresão's biography and the difficulties women writers, including those that were prolific and professional writers, faced at the time. The second section, "Choosing Female Friendship over the Romance Plot: Guiomar Torresão's Uma alma de mulher," explores her first novel elucidating how the plot and text structure substitute the conventional romance plot with friendships of support for women; creating spaces and choices for independent-minded women.

The third section, "Gender Consciousness and Literary Legacy in Ana Plácido" turns to the better known mid-nineteenth-century author questioning the critical reception on her as Camilo Castelo Branco's companion and writer. The last section "Herança de lágrimas: A Legacy of Letters" revisits Plácido's second novel discussing its formal complexities and exploring the ways in which discursive communities and legacies of women are developed within the multifaceted text.

\section{The Lettered Workwoman}

Born in Lisbon on November 26, 1844, Guiomar Delfina de Noronha Torresão died early, short of her $54^{\text {th }}$ birthday, from heart disease on October 1898 in the same city. In an obituary published in $O$ século she is described as "arguta, de espírito decidido e de vontade firme, correndo a cidade com o seu passo forte e ressonante, entrando mais em livrarias que em lojas de modas" (quoted in Castro et al., 2005: 379). She was a hardworking and prolific writer experimenting with a wide range of genres, including historic novel, fictional diary, travel narrative, novella, short story, poetry, and drama. She was also a critic, journalist, and translator and became a well-known editor and respected figure in the literary circles of her time. While not completely unprecedented, this was a unique fate for a Portuguese woman in the second half of the nineteenth century, especially if we consider that only later in her career would she gain support from eminent male scholars. Despite having been one of the period's most productive women writers and generally read during her lifetime, her vast work remains today largely unknown to readers and critics alike. The majority of her publications continue without contemporary re-editions, there are few critical readings or analyses of her writing, and these are mostly focused on her journalistic and editorial work.

A number of literary historians, such as Luiz Francisco Rebelo, consider her "a primeira mulher que em Portugal fez das letras a sua profissão" (1984: 9-10). Although unlikely to be the first —as Kathryn Bishop-Sanchez (2007) has shown Antónia Gertrudes Pusich (18051883 ), born in 1805 , supported her family primarily with her writingTorresão clearly belonged to as Fátima Outeirinho writes a "grupo de mulheres escritoras que farão do cultivo das letras um meio de subsistência" (1998: 165). In her book Operárias e burguesas Maria Alice Samara titles the chapter in her book dedicated to the writer: "Guiomar Torrezão: a operária das letras" (2007: 33-45). In 1880, she was the only woman to be part of the inaugural group that founded the "Associação dos Jornalistas e Escritores Portugueses" (Castro et al., 2005: 382). Pazos Alonso, writes that Torresão was, along with Maria Amália Vaz de Carvalho (1847-1921), one of the "better regarded female writers of the Geração de 70" (2016: 48).

Despite these unparalleled achievements, which allowed her, later in her career, to promote the creative and intellectual work of fellow female writers and to fight for the broader emancipation of women, her 
work and activity came at a high price. She encountered ample backlash, attacks, and criticism throughout her career. The Portuguese actress Adelina Abranches (1866-1945) writes in her memoirs, "Foi talvez a mulher mais ridicularizada pelos jornais humorísticos do seu tempo" (Samara, 2007: 36). In a letter published in 1913 in the Almanaque das senhoras, the annual Torresão founds and directs uninterruptedly from 1870 to 1898 , the republican intellectual, writer, and advocate for women's rights, Ana de Castro Osório (1872-1935), admits that Guiomar, "foi muito odiada, muito caluniada" (Castro et al., 2005: 379).

José Valentim Fialho de Almeida (1857-1911), an influential writer, collaborator, and friend of Guiomar Torresão, writes a substantial and often quoted essay published on the occasion of her death-and later included in his posthumous, Figuras de destaque (1923). Critical of Lisbon society's lack of respect and contempt for strong independent women, Fialho de Almeida describes the challenges Torresão faced:

Guiomar Torresão não tinha pai nem irmãos que exigissem contas aos desrespeitadores eméritos das mulheres sós; e não tendo constituído família, nem tendo fortuna própria, achou-se na condição de ter que ganhar ela mesma o seu prato e os seus vestidos, escrevendo para jornais todos os dias-isto é, cosendo à pena, em vez de coser à máquina, e não tirando deste esgotante martírio sequer talvez o que as pobres costureiras auferem nos armazéns onde trabalham. (1923: 189)

He censures this social rejection, classifying it as a "guerra ignóbil de muitos homens, contra uma mulher" (1923: 191). While Fialho de Almeida clearly admires Torresão's hard work and recognizes the importance of her literary voice at the time, he nonetheless seems to have little faith in the lasting impact of her writing. Like most critics, he describes her work within the context of her gender and contradicts himself in his assessment of her literary style. Fialho de Almeida's essay is very much like the preface ultra-romantic writer Tomás Ribeiro writes for Torresão's 1877 Rosas pálidas. Both of these examples show how at the time critical opinions written by men about female-penned literary writing were commonly ornate and ambivalent, more often disclosing gender biases than providing accurate readings of their work.

But an endorsement or support from a recognized male literary figure was at the time critical if a woman was to have any publication success. Notwithstanding a few exceptions, it is rare to find a novel, a collection of selected writings, or any volume written or compiled by a woman from this period that is not prefaced, edited, or supported in one way or another by a male figure. Thus, Guiomar Torresão worked continuously to collaborate and gain support from her male contemporary writers, and despite the many critiques, we know she maintained active intellectual dialogues with contemporary Portuguese writers including some fellow women writers such as Ana Plácido, Amélia Janny, and Maria Amália Vaz de Carvalho. In a collection of correspondence written in response to her own letters, and in her wide-ranging journalistic publications, we see how Torresão fostered collaborative communities, and created and incentivized public conversations between and about women. In her 1888 travel narrative, Paris: impressões de viagem, Torresão is especially feminocentric, imagining what Mary Louise Pratt (1992) identifies in the female-penned travel narratives she analyzes as feminotopias, or ideals of sisterhood. In a letter from 1873 included in the collection of correspondence, the Portuguese poet Amélia Janny, shares the enthusiasm she feels after reading Torresão's Rosas pálidas: "Como mulher e como portuguesa, pertence-me um bocadinho da sua glória..." (Herculano, 1910: 42-43). Women writers understood their work as belonging to a collective of like-minded women. This female-centered community of readers, writers, and companions I argue is imperative for understanding Torresão's life-long work. By looking closer at her first fictional publication, we can see the ways in which she fashions early on in her fiction these circles of women and collective female identities intra-textually. 


\section{Choosing Female Friendship over the Romance Plot: Guiomar Torresão's Uma alma de mulher}

Guiomar Torresão published her first novel at the age of twenty-two. A short novel of one hundred pages divided into fifteen chapters, Uma alma de mulher, is originally serialized in 1868 in the feminist periodical, $A$ voz feminina (1868-), which was initially directed by Portuguese writer and journalist, Francisca Wood (1802-1900). This weekly was the first to be published in Portugal that was explicitly outspoken on issues touching women's lives. Pazos Alonso examines the periodical and the writing of Francisca Wood, showing that besides being editor-in-chief, Wood was an inspirational mentor for a younger generation of women with literary aspirations. She describes how "an emergent nationwide female community generated from within the pages of the multifaceted periodical itself" (Pazos Alonso, 2017: 40-42). Similarly, in her novel Torresão was also pointing to and fostering female communities that would support alternative roles for women. The novel appears in 1869 in book form with an introduction by a respected male writer, Júlio César Machado (1835-1890).

While César Machado is impressed with the novel, he admits his support is purely coincidental. His friend and fellow writer, António Joaquim Abranches, wrote to him asking for some introductory words to the novel. Abranches, the young woman's godfather, died unexpectedly two months after this letter, and César Machado felt compelled to satisfy his friend's request claiming to write the preface in order not to disappoint the dead man. Abranches asks for César Machado's support because in the godfather's words, "essa menina tinha talento e não tinha fortuna, o que é o mesmo que dizer que era duas vezes pouco feliz" (Torresão, 1869: 7). Other than this initial albeit apprehensive backing from her godfather, and the "coincidental" support of César Machado, Torresão's successful literary career will be a result of her own efforts. César Machado admires the young writer's talent, audacity, dialogues, elegance of style, and what he identifies as an intuitive originality, and is occasionally condescending, describing her writing for example as "fantasia ardente

e juvenil, vocação imperiosa que o estudo há de aperfeiçoar mais tarde" (Torresão, 1869: 9-10).

Contrary to the above and in my reading, Uma alma de mulher is not merely an innocent first attempt at fiction writing by an inexperienced young woman, but a work conscious of its form and plot as it confronts romantic conventions and the romance plot, questions gender roles, and reflects on the writer's task within a broader discursive context. The heroine, Cecilia, narrates the story in the first person. She begins by telling the reader how after both her parents die custody is given to her wealthy aunt who is a baroness. At the age of ten she goes to live with her aunt, who remains distant to her niece and never replaces the mother's affection, thus intensifying the protagonist's sense of loss and loneliness felt from that moment on. A number of Torresão's short stories, novels, and plays have young motherless protagonists-this is a repeated topos in her work-her characters lack the trusted female guidance and affection they urgently seek. In fact, she regularly uses the figure of the orphan to describe her own condition as a woman writer. For Torresão the orphan epitomizes the experience of women writers and intellectuals in Portugal in the sense that they lack support, models, foremothers, and are abandoned by their own community of fellow male writers. She herself loses her father in 1853 when she would have been nine or ten years old, but we assume her mother lives an average life and in fact Uma alma de mulher is dedicated to her mother. With her orphaned young girls Torresão wants to underscore the figurative sense of loss and abandonment women experienced.

Thus, it does not surprise us that the crucial struggle for the orphaned Cecilia, who feels alone in the world, is the forging of a community of supportive friends and family. The novel is the story of the young woman's exploration and search for an environment that will uphold her independence of mind. Cecilia spends her adolescence on the baroness's Alentejo country estate, where they live until she is sixteen, when much to her dismay the aunt decides to move them to the capital to partake of Lisbon society. At different points throughout the novel Cecilia returns to her fond memories of her aunt's countryside home. Torresão creates 
a locus amoenus in this natural landscape and sets it in opposition to city life portraying it as something Cecilia seeks to regain. Furthermore, it was in this environment and setting that she first read key classical Romantic writers and masterpieces, Goethe (Werther), Victor Hugo, Madame de Staël (Corinne), Chateaubriand, among others. Juxtaposing the city and the country is a common trait in romantic narrative and while it is important in Torresão's story, it is also implied that the author is mindful of this dichotomy. She paints a portrait of a character educated on romantic novels and scenery, but as we shall see Cecilia does not let these or any idealistic notion or emotional extreme overwhelm her destiny.

The narrator dislikes the city balls, the gossip, and what she describes as society's hypocrisy and insincerity. Finding a friend and confidant in her cousin, Georgina, who is six years her elder, brings her much happiness and respite. The plot slowly develops, introducing a typical romantic love interest into the story. This is done very self-consciously, however, as if it were obligatory to include a romantic attachment. Readers, and the few women readers at the time, were accustomed to reading romance stories and one can argue Torresão is here trying to satisfy this expectation. Thus, by chapter three Cecilia discovers that she is in love with a young painter, Victor de Andrade, whom she meets through her aunt and who becomes a regular guest at their house. The protagonist is surprised, however, to find herself so love struck, "a chorar como uma louca!" and is unable to accept the intensity of her feelings, which she calls "semelhante loucura" (Torresão, 1869: 25). She resembles more a character playing the role of a romantic heroine, who every so often questions her part in the story, stepping out of it and reflecting on its plausibility. What we eventually discover is that the parallel story of female friendship between Georgina and Cecilia, and later between Cecilia and another friend Leonor, takes precedent over the romance story. This position of being both inside and outside a social role and specific set of expectations which Cecilia seems to be well aware of, is also one Torresão struggles with in that while writing in some sense a conventional romantic novel, the author likewise seeks out alternative choices for her female characters. Like her protagonist, Torresão while narrating a love story, does so hesitantly, and is in fact asking if such a plot is all that is possible. Might a female-penned romance plot end differently? Torresão exemplifies Rachel Blau DuPlessis's arguments in Writing beyond the Ending (1985), in so far as she attempts, as the twentieth-century writers studied by DuPlessis do, to provide an alternate ending that resolves the contradiction between Bildung or quest and romance or love (1985: 3-4).

The questions Torresão asks herself in narrating her story become evident in the complex ways in which the plot develops. Cecilia's aunt wants an older man, her confident, advisor, and friend, to marry her niece. This would be a beneficial marriage in terms of social status and economic convenience. Despite not loving the older man and being secretly in love with Victor, Cecilia finds herself initially accepting the proposal. Only after this first agreement, do Cecilia and Victor discover that their love is mutual, but both accept that under the circumstances they must sacrifice their happiness and respect the elders wishes. In a characteristically romantic fashion, the two lovers suffer the impossibility of being together. Cecilia, however, eventually refuses to accept the situation and decides on her own to confront her aunt's confidant confessing her love for Victor and asking the older man to give her up much to her aunt's despair.

Surprisingly kind and responsive, the conselheiro, as he is referred to throughout the novel, departs for Paris and gives up on the marriage. Despite his devotion to Cecilia, Victor is not central to the story and becomes increasingly less important as the plot develops. He is helpless and melancholic and because his tuberculosis worsens, he is sent to Madeira for repose. Thus, Cecilia seems to successfully distance from her life both male love interests, Victor and the older family friend. The baroness demands that her niece continues to be seen in society and one evening at a ball, Cecilia makes a new friend, Leonor. Until now her main interlocutor and confidant was her cousin and friend Georgina. However, she discovers that Georgina has falsely painted Leonor as greedy and someone who had attempted to seduce Victor. Instead, what Cecilia discovers from Leonor this evening is that Georgina is the one who in 
fact has been betraying the protagonist as she had been all along secretly in love with Victor.

Thus, a new female friendship ensues, and Cecilia and Leonor become now each other's closest friends. Because both of them have lost their mother they feel their bond to be especially strong. The narrator describes their friendship as a profound and true love, and the two women go to the same spot where Victor first confessed his love to Cecilia in the baroness's Benfica estate. There she reads a devastating letter from Victor, who writes passionately with his last words-he soon dies from his failing illness in his Madeira retreat. Thus, this repeated scene suggests that Leonor replaces or acts as a surrogate for Victor, as the romance plot and romantic emotional extremes are substituted by a story of composed female friendship. Despite briefly grieving for Victor, Cecilia soon finds happiness, living as she says only for Leonor: "não sentia que vivia senão pela amizade cada vez mais viva que me ligava a Leonor" (Torresão, 1869: 87). Her aunt dies a year later leaving Cecilia heir to a comfortable fortune. Now the protagonist can freely keep the company of Leonor and of the conselheiro, who in the meantime has returned from Paris and is still willing to marry Leonor. An older female cousin from the Alentejo has also come to reside with Cecilia in Lisbon, and the four family-like friends regularly enjoy each other's company.

The last two chapters narrate one long daytrip that the four characters take to Sintra to visit the historic sites and celebrate Cecilia's birthday. The protagonist describes how she walks along enjoying the pleasant day, "Apoiada no braço de Leonor, e a minha prima no do conselheiro," (ibidem: 98). She references the beautiful landscape and evokes Almeida Garret, Byron, and Bernardim Ribeiro. This locus amoenus sets the stage for her accepting a marriage to the conselheiro and symbolically echoes and recuperates the natural landscape of her childhood. The author brings her story to a close by circling back to a milieu populated by romantic imaginaries and literary influences while using the female friendships important for the protagonist to frame the novel. The union between Cecilia and the older man is not one joining two lovers but what seems like a marriage of three. When the decision is taken, the trio, Cecilia, Leonor, and the conselheiro, embrace in this idyllic environment: "Leonor abraçava-nos a ambos, rindo e chorando" (ibidem: 102). The newlyweds decide that Leonor will live with them. Cecilia says: "raptaríamos Leonor à sua família se tanto fosse preciso" (ibidem:102). The conselheiro and the older female cousin who remains living with them provide a sense of structure for the female friendship if not a legitimacy of what we might read as a queer affectionate union between two women. Cecilia ultimately finds in Leonor the expressions of love she had throughout the text longed for and desired or missed from her mother. There are repeated references to this physical affection: "Leonor lançou-me os braços ao pescoço," and "Leonor!... pronunciei enleada, ocultando o rosto no seu peito" (ibidem: 101). The affection between the two young women is often explicitly physical and sensual. On multiple occasions Leonor holds and caresses Cecilia: "apertando-me a mão com ardor" (ibidem: 77), "reclinando a fronte sobre o meu peito" (ibidem: 81), "assentamo-nos ambas com o braço enlaçado na cintura uma da outra" (ibidem: 85), "murmurou-me quase ao ouvido" (ibidem: 92), "murmurou ela com meiguice" (ibidem: 81), "enxugando-me as lágrimas" (ibidem: 81), "coloca-me sempre a mão nos lábios" (ibidem: 93), etc.

The four friends will eventually return to Cecilia's country estate in Beja where they will live happily together-they do have to give Leonor up to her own family during the four winter months. This moderation does not unsettle Cecilia and she concludes the story with a praise of friendship over romantic love.

O amor é uma visão deslumbrante; que as mais das vezes nos ilumina a vida, só para deixá-la morta e perdida sem remédio ao apagar-se!

A amizade é um cântico meigo e suave como o da mãe embalando o filho; um culto puro e imorredouro como o sacrário d'onde nasce e se difunde, a alma! (ibidem: 108, original italics).

Even if the narrator presumably refers to the friendship she feels for the conselheiro, what stands out most in the novel is the intensity and diversity of female friendships and Cecilia's desire to create a supportive community of primarily (although not exclusively) women. The 
italics also invite the reader to see beyond friendship in the word, as a queer reading of this unexpected ending and intimate friendship is possible especially considering the many references to the physical affection between the two women. The female friendship in Torresão operates structurally in the narrative as Tess Cosslett has shown in Woman to Woman (1988), not as a substitute for the male-female marriage but as a significant turning point in female identity and solidarity. The narrative shows the contradictions faced by a young mostly powerless protagonist, who nonetheless survives her own romantic plot and destiny and forges friendships and a self-identity that allow her independence and happiness.

Torresão mirrors her own coming of age as a writer in her protagonist's Bildung and search for communities of friendship. This is evident in the novel's interesting formal feature, which is that every chapter begins with an epigraph where Torresão quotes not only well-known French and Spanish romantic authors, but also, and perhaps more importantly, her own contemporary Portuguese male writers: Tomás Ribeiro, António Feliciano de Castilho, João de Deus, Teófilo Braga. On the one hand this is a strategic attempt to build a network of authors who could support her career, and a way of meeting readers expectations by proving that she is conscious of her literary milieu. On the other hand, this is also a way of inscribing herself in a literary circle by bringing that group of authors into her novel, thus placing her own narrative within that community, and thus forging a discursive bond between her writing and theirs, even if she and other women writers were in reality excluded from this literary milieu. Torresão's first novel reveals she was aware of social beliefs and literary conventions that restricted opportunities for women as individuals and writers. Its plot twists and focus on female friendships illustrates how the author forges alternative choices for her characters while responding to readers expectations. Uma alma de mulher is an example of how fiction penned by women at this time negotiate discursive trends and the dominant literary culture while imagining for their romantic heroines not only intellectual interlocutors and partners, but also supportive female friendships that were critical for their struggle for independence, emancipation, and happiness.

\section{Literary Reception and Gender Consciousness in Ana Plácido}

Like Portugal's eminent eighteenth-century woman of letters, Leonor de Almeida better known as Marquesa de Alorna (1750-1839), who was imprisoned along with her mother and sister in a convent in Lisbon for eighteen years, Ana Augusta Plácido (1831-1895), was also detained, first in a convent in Braga, and later between June 1860 and October 1861 , in a Porto prison because of her adulterous affair with the country's most celebrated romantic writer, Camilo Castelo Branco (1825-1890). Confinement provides both women, who actively cultivate their intellectual interests and literary aspirations during their imprisonment, with one of the two prerequisites later claimed by Virginia Woolf in A Room of One's Own (1929) as necessary for women's literary creativity to flourish. As Pazos Alonso writes of Plácido, "a prisão assegurou-lhe o tal quarto só seu, ou seja, um espaço propício à reflexão que potenciou o desenvolvimento de uma aguda consciência literária” (2012: 251).

The presumed failure or so-called sterility of nineteenth-century Portuguese women writers, which I argue has been the dominant discourse among literary historians, is particularly conspicuous when it comes to Ana Plácido. Despite being an accomplished novelist, whose writing meditates on and develops a strong literary and gender consciousness, as lover, companion, and eventually wife of Camilo Castelo Branco, Ana Plácido's literary reputation has been, as Hilary Owen points out, "overshadowed by her role in Camilo's dramatic life" (Owen/ Pazos, 2011: 111). In the words of Fernanda Damas Cabral, “Ana Plácido viu-se esmagada pela própria experiência romanesca. O seu nome nunca se autonomizou. Permaneceu sempre associado ao de Camilo" (1991: 20). Teresa Ferrer Passos presumes Plácido's feelings: "Ao lado do génio, sente-se cada vez mais a insignificante, se não mesmo a desajeitada que escreve" (1995: 193). Maria Ondina Braga summarizes how Pláci- 
do is commonly remembered: "é hoje lembrada por ter sido a amante e companheira do nosso maior romancista” (1988: 62).

Most literary histories, dictionary entries, biographical accounts, and even critical essays, neglect analyzing or considering her texts on their own terms focusing instead on Plácido's and Castelo Branco's allegedly ill-fated shared life. When it comes to her writing most critics prefer to stress her inability to sustain an enduring literary career after the publication of two books instead of admiring these contributions: $L u z$ coada por ferros, an eclectic collection of writings including six semi-autobiographical mediations and four short stories or novellas, is published in 1863 shortly after the affair with Castelo Branco became public, and Herança de lágrimas, a remarkable partly epistolary novel, is published in 1871. There were several other publications in periodicals including a number of novellas and a drama that began to be serialized but remained incomplete even though they were quite successful.

Not only have scholars mostly diminished the value of Ana Plácido's literary contributions, but even her role in Castelo Branco's personal life has been underappreciated and distorted. In an essay Paulo Motta Oliveira attempts to outline this lessening of her importance or what he calls calls "o apagamento sistemático de Ana" (2001: 199). He reviews the discursive reception that in the aftermath of Camilo's death literary historians begin to propagate, which increasingly belittles Plácido's style, ignores the significant influence she likely had on Camilo's life and work, and in the long run contributes to a systematic erasure of her memory. Thus, it has been difficult to envision her impact as a woman writer on Portuguese nineteenth-century literature.

Nevertheless, a handful of critics have endeavored to highlight the importance of Plácido as a proto-feminist writer in the Lusophone literary context. Allegro de Magalhães speaks of the "grito feminista que sai das páginas de Ana Plácido" claiming the writer presents "um discurso todo ele marcado por uma visão feminista avant-garde em Portugal" (1987: 499). Pazos Alonso and Damas Cabral (1991) are two scholars that contemplate Plácido's literary legacy by reading and analyzing some of her fictional writing. Pazos Alonso shows "o percurso de Plácido li- terário como manifestação expressiva duma reivindicação artística coerente" (2012: 249). Building upon their work, I elucidate unique features of Plácido's writing that I hope sheds positive light on the rather cynical assessment we have of her figure and fictional production.

Plácido, not unlike Torresão, adopts a position of critique within the conventions of romanticism by strategically modifying these in her narratives. In line with what Elizabeth Fay asserts in A Feminist Introduction to Romanticism (1998), Plácido has a complex relation to romanticism, absorbing conventions and stereotypes, while also dissenting from some of the movement's precepts. In addition, Plácido's stories and writings privilege female solidarity and attempt to build a consciousness of a legacy of women writers, readers, and intellectuals. She gives voice to the female-centered perspective and appears mindful of her writing as fitting into a broader aesthetic and literary context. Her writing is an ongoing reflection and attempt by a novelist to question the role the woman writer has in defining the narrative genre and the literary legacy she leaves specifically for the women writers who might follow in her footsteps. Sharon Marcus has shown in Between Women (2007), how the complex communities and interactions in the diversity of relationships and friendships among women in Victorian England provide us with unexpected experiences that in turn question traditional views of femininity and gender roles. Likewise, Plácido creates with her writing a female community, even if only an imaginary or fictional one, which would allow women to confront society's restrictive dictates and consider diverse social roles for women and relationships among them.

Most critics emphasize that Ana Plácido's writing is autobiographical and intimately linked to her personal experiences. Aníbal Pinto de Castro describes Plácido's writing as an "amálgama onde se torna difícil, senão impossível, definir fronteiras" between autobiography and fiction (1995: 20). Cabral writes: "É como se tivesse ficcionado a sua autobiografia, desmultiplicando-a em várias narrativas biográficas imaginárias" (1991: 121). There is no denying that Plácido’s life would have influenced her writing, for it was, as biographers have extensively written, anything but uneventful. Born in 1831 into a large Porto family 
belonging to the city's commercial bourgeoisie, Plácido is forced for material interests by her father at age 19 to marry Manuel Pinheiro Alves in 1850, who was 24 years her senior. Pinheiro Alves was a returnee emigrant who went to Brazil and successfully made his fortune. The loveless marriage lasts until 1859 when her affair with Camilo Castelo Branco becomes public. Upon losing both her parents - her father in 1852 and her mother in 1855- and the sister that seems to have been closest to her, Maria José, to tuberculosis in October 1858, just two months after the birth of Plácido's first son, Manuel, the young mother decides to leave her husband at the beginning of 1859 with her infant son to live with Camilo. In July of that same year she accepts her husband's proposal and is temporarily confined in the Conceição convent in Braga. Shortly after, the lovers plan her escape from the convent and Plácido again joins Camilo in Porto. The two lovers are eventually arrested, imprisoned, and in October 1861 absolved of their crime. Reunited they first live in Porto and then in Lisbon, and in 1863 their son Jorge is born. Following her first husband Manuel Pinheiro Alves's death in 1863, her older son, Manuel, inherits the property and house in S. Miguel de Ceide in Vila Nova de Famalição, where the family settles into in 1864, the year their son Nuno is born. Ironically this estate is today home to the Casa-Museu de Camilo. The couple will only officially marry in 1888, just two years before Camilo, who was growing progressively blind and whose physical and emotional health was steadily deteriorating, commits suicide by shooting himself. Besides financial difficulties, they experienced many familial tragedies, including the death of Plácido's older son Manuel in 1877, and the extremely troubled lives of the couple's two other sons. Jorge supposedly had severe mental health issues, and Nuno marries Maria Isabel Macedo, who along with their baby daughter, tragically die three years after the elopement of the couple.

All of these personal fatalities have led critics to underscore how these melancholic experiences filled Plácido with feelings of guilt and regret and limited her ability to write. In Ferrer Bastos's words "limitaram, sem remédio, o talento e a predisposição literária de Ana” (1995: 198). This crossing between life and fiction is common for the period

and strengthen literary romanticism's correlations to subjectivity and autobiographical writing. Camilo intertwines autobiographical experience with fiction and the merit of his literary production is not underestimated as a result. While it is true that much of Plácido's writing might be read as being entangled with the personal difficulties she faced, it is equally noteworthy that many of the fates of her protagonists purposely differ from her own.

\section{Herança de lágrimas: A Legacy of Letters}

Published in 1871 using her male pseudonym, Lopo de Sousa, the front cover of the first edition of Herança de lágrimas includes a quote from George Sand's Lélia (1833). Opposite the title page is a picture of Plácido with the words, "D. Ana Augusta Plácido / Autora deste livro" written in script below the image. Why would you use a pseudonym and simultaneously and unmistakably own your authority as writer of a text? This contradiction gives the novel from the onset a multifaceted puzzling quality that makes the reader question the role, nature, and independence of a writer. Is the author of this novel a man or a woman? Are Georg Sand and Lopo de Sousa male or female? How are we to think of these pennames? Or is perhaps the duality intentionally marked in order for the reader to reflect on the nineteenth-century woman writer as an androgynous multifaceted figure? The uncanny presence of the self-portrait questions the position and confines of the female author. Similarly, once we begin reading and slowly discover the novel's complex structure, we are faced once again with several pairs that are juxtaposed as on the front cover: multiple narrators, more than one implied reader, and texts within texts.

The framework of the novel, or this doubling process, purposely splits narratives into parts, and individuals into multiple characters. It is as if women writers and female characters are never alone, whole, or individual, but belong instead to a collective, to another, or as the story implies, to a community of readers and writers. I argue that it is the unique bond created in the novel between writing and reading that con- 
nects the female protagonists to one another. As we shall see, the mother and daughter protagonists of the story, and several other women in the novel as well, are united intellectually, literarily, and through writing as the narrative shapes a feminine-centric textual genealogy. Only on a less important second level are they also linked by their interrelated romantic experiences. Just as Torresão, Plácido relegates the romance plot to a second-place position giving precedence to the female friendships and legacies structured in the narrative.

The novel is divided into two interrelated but separate narratives. The first part consists of eleven chapters or letters written, with the exception of one, by the female protagonist, the twenty-seven-year-old $\mathrm{Di}$ ana de Sepúlveda. Having recently travelled to Lisbon with her much older husband, Álvaro de Sepúlveda, Diana writes to her childhood friend Henriqueta D'Aguiar who lives in the north of Portugal and who is the author of the one exceptional letter that is not written by the protagonist. Diana recounts details of her new life in the capital and shares her intimate emotions, fears, hopes, often calling her writing a dissertation or a confession. Details in the letters reveal that the two women are portrayed as honorable characters, clearly well read, and intellectually curious. There are constant references to their strong intelligences and to their active reading and writing habits. In her first letter to Henriqueta, Diana asks, "Perguntas-me tu agora quem me ensinou tanto. Respondo: não a experiência, graças a Deus, mas o estudo que tenho aproveitado de mil exemplos" (Plácido, 1871: 9). From the beginning it is stressed that Diana is devoted to a life of the mind which Henriqueta seems to be able to relate to. Beatriz, a good friend of Diana's whom she meets in Lisbon, and the sister of Nuno d'Alvarães, the protagonist's ensuing love interest, refers to Diana's intelligence on several occasions, at times complaining about her recluse nature: "mas eu sei que vives e que passas o tempo lendo, escrevendo e sonhando como sonha a tua rica imaginação" (ibidem: 55). Nuno is impressed by Diana's and Henriqueta's education which he can discern from reading Henriqueta's letters, which we are told are shown to him by Diana. Unlike Nuno we only have access to the one letter from Henriqueta. The readers draw similar conclusions however to

Nuno as we read Diana's contemplative, self-reflective letters packed with historical and literary references.

As remittee of the letters, Henriqueta d'Aguiar is clearly a "characterized" or fictional reader who has access to the same set of texts that we as readers have. Thus, we identify with Diana's interlocutor and she can also be considered an implied reader in accordance with Wolfgang Iser's definition (Wilson, 1981: 848). Moreover, she has multiple reading duties besides reading Diana's correspondence or the first half of the novel. Henriqueta is also the implied and fictional reader of the important manuscript that surfaces toward the end of the first part of the novel and becomes the second and longer section of Herança de lágrimas or the text within the text. This, we discover, is a diary or narrative written by Diana's up-until-this-point unknown mother, Branca d'Alvarães. Branca, our other protagonist, as we eventually learn toward the end of her narrative, will write her life story on her deathbed immediately after giving birth to Diana, with the intention of leaving the diary for her daughter to read one day. This text within the text is introduced abruptly into the narrative. Toward the end of the first part of the novel, exactly at the moment when Diana is about to consummate an adulterous affair with Nuno, her husband Álvaro surprises the young couple, interjecting and thus stopping the affair from taking place. At this point, Álvaro gives Diana her mother's manuscript and Diana discovers what had always been kept from her: the identity of her mother and the ill-fated adulterous story of her parents. In wishing to hide from Diana her mother's tragic death, everyone in the protagonist's life had kept her mother's identity and unhappy life story a secret from her. As she is handed the manuscript to read and discover her legacy the self-discovering process of letter writing, or her unfolding subjectivity, comes to a close since the first part of the novel ends here.

But, just as Álvaro intrudes on the lovers with the manuscript, a new narrator interrupts the novel at this point saying "Temos à vista 0 curioso manuscrito enviado por Diana de Sepúlveda à sua amiga" (Plácido, 1871: 103-104). Thus, it appears, Diana trusts her friend, Henriqueta, to the point that she sends her Branca's manuscript, presumably after 
reading it first herself. It would not be necessary to make both young women fictional readers of Branca's text, yet the fact that they are is not coincidental. This solidifies their close friendship and gives their bond a sort of literary or discursive continuity. Moving the manuscript from the hands of one woman to another inspires multiple possible readings: might Henriqueta be the narrative voice that interrupts at the end of part one and rewrites Branca's story? Because, as we shall see the narrator chooses to modify Branca's text. Is Henriqueta, then, besides an avid reader, also a writer hiding behind a penname, like Lopo de Sousa? Ultimately it is not relevant to determine who the narrator might be, but to note that Plácido purposely complicates and conflates these figures emphasizing the manifold and significant part women have as readers, writers, thinkers, learners. This constant role playing of female readers and writers is central for the structure of the novel. Diana is divided into two characters within this first part because she is in almost all respects like Henriqueta, both a reader and writer (of letters, books, her mother's manuscript). The novel puts emphasis on the fact that they are like sisters and notes the importance of having been educated together. What unites them most is having been tutored in their early years by their intellectual mother, "a nossa excelente mestra e quase segunda mãe, senhora de grande inteligência e grandes virtudes" (Plácido, 1871: 44). Where they differ is very specifically in their romantic fates, and this is also not coincidental. While Henriqueta is happily married with children, Diana was coerced into a loveless marriage with an older man. Plácido intersects the destiny and the reader/writer roles of these two women, or of this double, in order to create a community or a collective of educated women, something central throughout the story, as we shall subsequently see.

As we begin to read part two of the novel, Diana has now another double, her mother. Her own life is both echoed and prefigured in her mother's experience. Instead of reading Branca's first-person narrative, however, we are given her account, as mentioned above, in a modified state. The narrator that interrupted earlier comments: "Entendemos, porém, dar-lhe a forma narrativa como mais agradável ao leitor, e de melhor feição para expor os lances e episódios d'um amor infeliz" (Plácido,
1871: 104). Taking a woman's diary and turning it into narrative prose is an authorial discursive practice. The narrator is mostly all-knowing and objective but remains in the first person and identifies himself as male reinforcing the relation between the narrator and Plácido's penname Lopo de Sousa. This intervening narrator sympathizes strongly with the protagonist, while still having the confidence and authority to usurp Branca's story and make it his own. Her voice is not wholly silenced, however, as the text focuses primarily on her thoughts, emotions, and includes many direct quotes of her speech. In fact, this narrative trait has ultimately the effect of bringing the male narrator and Branca's character closer, collapsing the authoritative male voice with a woman's knowledge and experience.

Despite identifying himself as male, the narrator harshly criticizes men and society's gender biases and double standards throughout the narrative. As the narrative centers around Branca's story of adultery, love, beauty, marriage, and motherhood, the narrator's comments and the narrative worlds depicted are predominantly of a feminine nature. These circumstances and the occasional humility and false-modesty of the narrative voice result in Plácido's narrator having more in common with other nineteenth-century female narrators than with a conventional male or omniscient narrator. The doubt professed from the outset on the front cover of the novel about the gender of authorial voice is continually questioned throughout the narrative by the entangling of intruding male characters and narrators (such as Diana's husband Álvaro and the unidentified male narrator that decides to alter Diana's text) with female readers and writers (Diana, Henriqueta, Branca). Plácido begins to pose theoretical questions in this novel that Clarice Lispector will take up a century later emblematically in her novel $A$ hora da estrela (1977). There are similarities worth noting between Lispector's playful title page and Herança de lágrimas's front cover. Plácido questions not only gender specificity but also asks who has authority over a text? While women might not always have been the authors or the narrators of stories, their voices and experiences are central to them, even if at times these were usurped or distorted by male writers. 
This complicated literary or discursive legacy is implied in the title of the novel, Herança de lágrimas, which refers presumably to Diana's inheritance of her mother's tragic love story. Yet, Diana has much more in common with Branca than merely her mother's doomed romance. Diana inherits from her mother a story, a text, so that the title of the novel can refer instead to an imagined, or a discursively created legacy connecting women emotionally but also intellectually. Both mother and daughter are passionate for books and knowledge, and they receive, albeit limited, varied and excellent educations. Thus, although both narratives, Diana's and Branca's, tell stories of adultery or possible adultery, their independence, intellectual dispositions, propensity for thought, and vocation to a life of the mind, are as important legacies as are the amorous affairs.

The narrator describes Branca's intelligence: "Branca pensava que nascera para a vida do estudo, sem compreender que houvesse homem que lhe fizesse esquecer os seus livros e o seu gabinete" (Plácido, 1871: 121). All the men in Branca's life will resent her for this, often insulting her. Her husband Jorge says to her sarcastically, "Perdoe a minha literata" (ibidem: 133). Branca's lover Rodrigo is no less cruel and misogynist. Once Branca abandons Jorge and escapes with Rodrigo to the north of the country, the couple end up living in a small secluded rented house in the outskirts of Porto and their relationship quickly and increasingly deteriorates. Aware of her intellectual superiority, Rodrigo expresses his frustration out on Branca and reacts patronizingly to Branca's wishes to earn her own living and contribute to the couple's expenses by working as a schoolteacher. In fact, a thinking woman seems to be what is most feared by all the male lovers in the novel, Nuno, Rodrigo, and Jorge.

Ultimately, Branca refuses to tolerate Rodrigo's cruel mistreatment and abandons him returning to Lisbon to stay temporarily at the house of a poor woman widower, a cousin of her former servant Maria. These lower-class women who are very aware of gender biases and inequalities are crucial in their support of Branca. Maria and her cousin are also the ones that realize Branca is pregnant and get her a position in the house of the good-natured and kind widow, D. Catarina. Branca becomes a tutor to D. Catarina's two young daughters, the oldest of which serves as godmother to Branca's daughter when she is born giving the child her name, Diana. This community of women supports and bequeaths money, names, and narratives to one another. In addition, this shared spirit can only take place in the absence of men-that is why it is important that the two women that take Branca in are widowers with authority in their own homes. While Plácido characterizes a few women as vain and traitors to their gender, the majority of her female characters provide a community of care for her protagonists.

Like Branca's, Diana's intelligence is also manifested throughout the first part of the novel. In one of her letters, Diana tells of an evening spent with Nuno, his sister Beatriz, and their father, the count. The group discusses poetry comparing and contrasting classical writers from the Portuguese literary canon with more recent French literary trends. During the literary soirée, Diana leafs through one of the books from the count's library and is particularly moved by an edition of the classical Portuguese tragedy Castro (1598) by António Ferreira (1528-1569). In it she finds two handwritten lines: "O livro que mais amei na minha infância-Branca d'Alvarães" (Plácido, 1871: 70). In the letter to Henriqueta, Diana shares the words she directed at the count:

Quando vejo uma página d'estas sinto-me tomada d'uma espécie de veneração por essas criaturas que viveram, pensaram e amaram, e que hoje jazem desfeitas no pó, sem deixarem talvez na terra quem as chore, ou aprecie seus legados. E, perdoe-me v. ex. a a rudeza das minhas expressões, magoa-me o olvido em que achei este livrinho, e que prova o destino de sua dona. (ibidem: 71)

Diana's identification in the above scene with a former female reader, who is also as we will subsequently learn, her mother, reinforces the ways in which the novel inscribes women into a forgotten or overlooked literary legacy. As no women writers are an integral part of the all-male literary canon discussed by the group, this signature inscribed in the margins of a text whose protagonist is also a strong woman condemned for her love and devotion, interrupts that literary history and is a way of calling attention to the supposed absence or silent presence of 
women readers and writers (if not of canonical literature than of letters, diaries, etc.).

Similarly, the fragmented epistolary novel with its indirect signature and photograph of the woman/male author-is a way for Ana Plácido to intervene in a literary tradition. There is a correlation created between this small forgotten edition of Castro in which Diana discovers her mother's name, the manuscript written by Branca and inherited by Diana, and Plácido's own novel. Herança de lágrimas is a compilation of pieces of female-authored texts recreating thus a whole out of the fragmented pieces authored and read by women. Women have a discursive or literary history that is evident in every reader of literature, writer of letters, diaries, accounts, every woman that wrote with a penname, or on the margins of books. They are not only vulnerable characters in romantic plots, or protagonists of doomed love stories, but more importantly they belong to a female community that has left a legacy and discursively inscribed its gender consciousness. This bequest is evident in the names of the various female characters which seem to contain the author's own name Ana, within it, such as Diana, Branca, Catarina, and as mentioned earlier, D. Catarina's own daughter gives Diana her name. It is as if a secret linguistic code brings the women in the novel and women in general together. They are connected literarily by different letters, epistolary and alphabetical, but they are also connected by their collective intersecting reading and writing.

\section{Conclusion}

Pazos Alonso points to how Plácido inscribes in her fiction a "comunhão de almas femininas" (2012: 252). Clearly in Herança de lágrimas we see this community of women who help each other, but what is less explicit and more intricately woven into the complex structure of the text is this discursive community of women readers and writers, many of which were forgotten, silenced or had their stories usurped. Like Torresão, Plácido's story is also a romance plot, suspenseful and full of the trials the different lovers faced. Both were aware of the literary conven- tions at the time and were responding at some level to readers expectations. The two novels, however, choose not to give prominence to the romantic adventures and instead focus on female friendships. They write a story that also poses narrative and theoretical questions about what authority does a women writer have, and what alternatives, possibilities, and choices present themselves for young educated women in Portugal's patriarchal society of the nineteenth century. Connections between the female characters are created within the framework of the novel attempting to link friendships and collectives of women to broader narrative questions about the possibility of a narrative genre in Torresão's case, or about creating legacies of women readers and writers within textual margins. Both Plácido's and Torresão's narratives are meta-constructions that as we have seen quite intentionally create within the text a consciousness of female friendships, heritages, and bonds, that show the authors' concern for not only telling stories about women but telling the public readership about the untold stories of women. Their novels build connections that inscribe women into a community of shared knowledge and intellectual activity, thus penning and engraving in this way women's legacies and their own as women writers.

Received: $10 / 07 / 2020$

Accepted: 19/10/2020

\section{Works cited}

Almeida, Fialho de (1923), Figuras de destaque. Livraria Clássica.

Barros, Teresa Leitão de (1924), Escritoras de Portugal: génio feminino revelado na literatura Portuguesa, n.p.: n.d., 2 vols.

Bishop-Sanchez, Kathryn (2007), "Mulheres invisíveis: a escrita no silêncio", Portuguese Literary \& Cultural Studies, 12, pp. 169-82.

Braga, Maria Ondina (1988), Mulheres escritoras: da biografia no texto ao texto da biografia, Amadora: Bertrand. 
Cabral, Fernanda Damas (1991), Ana Plácido: a autobiografia como processo genealógico de escrita, Lisboa: Caminho.

Castro, Aníbal Pinto de (1995), Ana Plácido: a mulher que se maravilhou a si própria, Vila Nova de Famalicão: Câmara Municipal.

Castro, Zília Maria Osório de et al. eds. (2005), Dicionário no feminino: séculos XIX-XX, Lisboa: Livros Horizonte.

Cosslett, Tess (1988), Woman to Woman: Female Friendship in Victorian Fiction, Brighton: Harvester Press.

DuPlessis, Rachel Blau (1985), Writing beyond the Ending: Narrative Strategies of Twentieth-Century Women Writers, Indianapolis: Indiana UP.

Fay, Elizabeth A. (1998), A Feminist Introduction to Romanticism, Oxford: Blackwell.

Magalhães, Isabel Allegro de (1987), O tempo das mulheres: a dimensão temporal na escrita feminina contemporânea, Lisboa: Imprensa Nacional-Casa da Moeda.

Herculano, Alexandre (1910), Trechos literários de Alexandre Herculano e cartas do mesmo e de outros escritores ilustres a Guiomar Torresão: colecionadas, publicadas e editadas por sua irmã, com prefácio por Dr. Armelim Júnior, Lisboa: Typ. Leiria.

Marcus, Sharon (2007), Between Women: Friendship, Desire, and Marriage in Victorian England, Princeton, N.J. / Oxford: Princeton University Press.

Oliveira, Paulo Motta (2001), “Considerações acerca do apagamento de uma Ana Pouco Plácida", in Silvio Renato Jorge and Ida Maria Santos Ferreira Alves (eds.), A palavra silenciada: estudos de literatura portuguesa e africana, Río de Janeiro: Vício de Leitura, pp. 199-210.

Outeirinho, Maria de Fátima (1998), "Guiomar Torrezão ou memória de uma mulher de letras oitocentista”, Intercâmbio, 9, pp. 163-176.
Owen, Hilary and Cláudia Pazos Alonso (2011), Antigone's Daughters? Gender, Genealogy, and the Politics of Authorship in Twentieth-Century Portuguese Women's Writing, Oxford: Bucknell UP.

Passos, Teresa Ferrer (1995), O segredo de Ana Plácido. Romance, Lisboa: Gazeta de Poesia, 1995.

Pazos Alonso, Cláudia (1996), "Becoming Visible", in Cláudia Pazos Alonso and Glória Fernandes (eds.), Women, Literature, and Culture in the Portuguese-Speaking World, Lewiston: Edwin Mellen Press, pp. 23-37.

--- (2012), “Ana Plácido, uma escritora oitocentista exemplar", in Petar Pretov et al (eds.), Avanços em literatura e cultura portuguesas. Da idade média ao século XIX, Santiago de Compostela/ Faro: Associação Internacional de Lusitanistas (AIL)/ Através Editora, 249-265.

--- (2016), "A Newly Discovered Novel and its Transnational Author: Maria Severn by Francisca Wood", Portuguese Studies, 32.1, pp. 48-61.

--- (2017), "Modernity in the Making: The Women at the Heart of $A$ Voz Feminina and O Progresso", in Ana Luísa Vilela, Fabio Mario da Silva, and Maria Lúcia Dal Farra (eds.), O feminino e o moderno, Lisboa: CLEPUL, pp. 37-57.

--- (2020), Francisca Wood and Nineteenth-Century Periodical Culture: Pressing for Change, Cambridge: Modern Humanities Research Association.

Plácido, Ana Augusta (1904), Luz coada por ferros, Lisboa Parceria António Maria Pereira.

--- (1871), Herança de lágrimas: romance original por Lopo de Souza, Guimarães: Vimaranense Editora.

Pratt, Mary Louise (1992), Imperial Eyes: Travel Writing and Transculturation, London: Routledge.

Rebelo, Luiz Francisco (1984), 100 anos de teatro português (1880/1890), Porto: Brasília Editora. 
Samara, Maria Alice (2007), Operárias e burguesas: as mulheres no tempo da República, Lisboa: A Esfera dos Livros.

Torresão, Guiomar (1869), Uma alma de mulher, introdução por Júlio César Machado, Lisboa: Tipografia J. G. de Sousa Neves.

--- (1877), Rosas pálidas: narrativas originais, precedidas de uma carta de Tomás Ribeiro, Porto: Livraria Portuense.

--- (1888), Paris: impressões de viagem, Porto: Livraria Civilização.

Wilson, W. Daniel (1981), "Readers in Texts", PMLA, 96, no. 5, pp. 848863. 